\title{
Evaluation of the Diabetes Contribution to the Occurrence of Treatment Related Toxicities in Multimodal Treated Locally Advanced Head and Neck Cancers
}

Camil Ciprian MIRESTEAN, Ovidiu Nicolae PAGUTE ${ }^{1}$, Simona CARDEI ${ }^{2}$, Raluca APOSTU², Calin BUZEA, Catalina TEACA', Ramona ROMAN', Roxana Irina IANCU ${ }^{3,4}$, Dragos Teodor IANCU1,4

\begin{abstract}
Diabetes mellitus is often associated with a risk of developing some types of cancer. The association between head and neck cancers and diabetes as well as prognosis and treatment tolerance remains a controversy. Acute toxicities associated with treatment may be amplified by the presence of comorbidities, including hypertension, diabetes and collagen diseases. Another factor implicated in the treatment tolerance is also the limitation by the presence of hyperglycemia of the corticosteroids dose used for the control of pain and edema associated with chemo-irradiation and for the treatment of thrombocytopenia. The purpose of the study was to evaluate the involvement of diabetes mellitus in the toxicities associated with chemo-radiotherapy treatment in multimodal treated patients for advanced local head and neck cancers. For patients with locally advanced non-metastatic head and neck treated with multimodal (chemo-radiotherapy) acute toxicities (radio-dermitis, radio-mucositis, dysphagia) was analyzed comparatively in patients who associate or not cancer with diabetes. It was also compared if the diagnostic of diabetes influenced the intensity of chemotherapy. Identifying the predictive value of diabetes mellitus for the severity of toxicities in multimodal curative treatment for head and neck cancers can lead to limitation of radiation dose to some radiosensitive anatomical structures in the context of the modern IMRT and VMAT irradiation techniques implementation in clinical practice.
\end{abstract}

Keywords: diabetes, head \&neck cancers, toxicity, radiotherapy, chemotherapy.

\section{Rezumat}

Diabetul zaharat este adesea asociat cu riscul dezvoltării unor tipuri de cancer. Asocierea dintre cancerele capului și gâtului și diabetul zaharat, precum și prognosticul și toleranța la tratament rămâne o controversă. Toxicitatea acută asociată cu tratamentul poate fi amplificată de prezența comorbidităților, incluzând hipertensiunea, diabetul zaharat și colagenozele. Un alt factor implicat în toleranța la tratament este și limitarea prin prezența hiperglicemiei a dozei de corticosteroizi utilizată pentru controlul durerii și edemului asociat cu chimio-radioterapia și pentru tratamentul trombocitopeniei. Scopul studiului a fost de a evalua implicarea diabetului zaharat în toxicitatea asociată tratamentului multimodal (chimio-radioterapia definitiva) la pacienții cu cancere local-avansate ale sferei O.R.L. Pentru pacienții care au asociat sau nu boala malignă local avansată, non-metastatică cu diabetul zaharat au fost

\footnotetext{
${ }^{1}$ Regional Institute of Oncology, Iasi, Romania

${ }^{2}$ Emergency Hospital, Bacau, Romania

${ }_{3}$ "Sf. Spiridon" Emergency Clinical Hospital, Iasi, Romania

${ }^{4}$ "Gr.T.Popa" University of Medicine and Pharmacy, Iasi, Romania
}

\section{Corresponding author.}

Irina Roxana IANCU, Department of Oral Pathology, " Gr. T. Popa" University of Medicine and Pharmacy, 16 University Street, 700115. Iasi, Romania.

E-mail: rox_iancu@yahoo.com, riiancu@umfiasi.ro. 
analizate comparativ, toxicitățile acute inregistrate pe parcursul radio-chimioterapiei și in primele săptămâni după tratamentul multimodal (radiodermită, radiomucozită, disfagie). De asemenea, a fost evaluat rolul diagnosticului de diabetului asupra protocolului si intensității regimurilor de chimioterapie. Identificarea valorii predictive a diabetului zaharat pentru severitatea toxicității în tratamentul curativ multimodal pentru cancerele capului și gâtului poate duce la limitarea dozei de iradiere primite de unele structuri anatomice radiosensibile în contextul implementării a tehnicilor de iradiere moderne (IMRT și VMAT) în practica clinică.

Cuvinte cheie: diabet, cancere ale capului și gâtului, toxicitate, radioterapie, chimioterapie

\section{INTRODUCTION}

Head and neck squamous cell carcinoma accounts for approximately $6.5 \%$ of cancer cases with anoverall survival at 5 years of approximately $55 \%$. Recent research has focused on identifying new molecular targets in the context of a precision medicine. It is also necessary to evaluate the host factors associated with a higher risk of recurrence and mortality, or that can modulate treatment tolerance ${ }^{1}$. Cancer has in common with diabetes increased insulin and IGF-1 secretion, metabolic alterations and changes in the immune system with the release of pro-inflammatory cytokines. Historically, cancer has been seen as an abnormality in proliferation, but modern vision includes neoplasms among metabolic diseases. Malignant cells reprogram metabolism in order to provide their nutritional substrate adapted to their needs. Tumor cell causes increased consumption of glucose and glutamine and increased glycolysis ${ }^{2}$. Hyperglycemia is defined as a blood glucose of more than $126 \mathrm{mg} / \mathrm{dL}$ or random blood glucose above 200 $\mathrm{mg} / \mathrm{dL}^{3}$. Factors including diabetes mellitus, obesity, pancreatitis, chronic stress can cause hyperglycemia. Cancer is recognized as a chronic condition also associated with hyperglycemia considered associated with being associated with tumorigenesis or tumor progression. Epidemiological studies have highlighted a link between the presence of diabetes and the development of a large number of solid tumors. The most common associations were between diabetes and hepatic and pancreatic cancers, with a higher incidence than the general population ${ }^{4}$.

\section{MATERIALS AND METHODS}

The study included 25 patients diagnosed with locally advanced, non-metastatic squamous cell carcinoma of the head and neck. Patients were evaluated for tumor staging using pretreatment CT imaging followed by a new CT evaluation after 2-4 cyclesinduction chemotherapy. Induction chemotherapy included plati- num-salt monotherapy, platinum doublets taxanesplatinum doublet (TP), platinum-5-fluorouracil (PF) or triple platinum-taxane-5-fluorouracil (TPF). Seven patients received Carboplatin or Cisplatin monotherapy, 14 patients received TP or PF platinum doublet and 4 patients received triple association (TPF) protocol. Subsequently, all patients received curative intent radiotherapy in a total dose of $70 \mathrm{~Gy}$ in 35 fractions using intensified modulated radiotherapy (IMRT) or volumetric arc therapy (VMAT) techniques. The RECIST/ RECIST 1.1 criteria were used in all cases to evaluate the imaging response to induction chemotherapy. Response to induction chemotherapy was assessed by imaging methods as complete response, partial response, stationary disease and progressive disease. All patients who did not benefit from post-induction chemotherapy imaging evaluation (CT or MRI), who received less than 2 cycles and more than 4 cycles of chemotherapy, were excluded from the study. Also excluded were patients who were evaluated at more than 60 days after the last cycle of chemotherapy. Five patients in the study group were diagnosed with diabetes at the time of the cancer diagnosis and one patient was diagnosed after the histopathological confirmation of the malignant diagnosis. Four of the patients were treated with oral antidiabetics and one patient was treated with insulin. Two of the diabetic patients experienced infectious complications and hospitalization that required delay of the radiotherapy.

\section{RESULTS}

All patients developed toxicity during treatment. $\mathrm{Ra}$ dio-mucositis and dysphagia occurred most frequently starting from the $2^{\text {nd }}$ week of treatment, requiring symptomatic treatment in all cases. All patients developed toxicity during treatment. Radio-mucositis and dysphagia occurred most frequently starting from the $2^{\text {nd }}$ week of treatment, requiring symptomatic treatment in all cases. There was 2 grade from 4 acute toxi- 
city (mucositis) after multidisciplinary treatment, one in the non-diabetic patents lot and one in the diabetic patients group. Hematologic toxicity (anemia, lymphopenia, thrombocytopenia) was present in equal proportions among diabetic and non-diabetic patients. radiomucosity and chewing disorder were more prevalent amongst patients with floor cancers. A diabetic patient treated with metformin for 2 years presents a high had blood glucose level (>160mg/dl) after iv Dexamethasone administration ( $4 \mathrm{~g} /$ day) for 2 weeks. 3 patients, including one diabetic patients, required discontinuation of treatment between 2-6 days due to thrombocytopenia $(<75.000$ per microliter).

\section{DISCUSSIONS}

Foreman et al. tries to elucidate the controversy over the influence of diabetes on the survival of treated patients for head and neck cancers. His analysis demonstrates no different between the diabetic $(64 \%, 95 \%$ CI $=58 \%-71 \%)$ and nondiabetic $(67 \%, 95 \% \mathrm{CI}=65 \%$ $-69 \%, \mathrm{P}=.078)$ analyzing overall survival for 5 years ${ }^{5}$.

The impact of comorbidity on tumor and treatmentspecific outcomes in head and neck squamous carcinoma was analyzed by Singh et al. but the authors did not identify in a study including 70 diabetic patients radio-chemotherapy treated, an increased rates of treatment-associated complications ${ }^{6}$. Charlson comorbidity index was also found to be a valid prognostic indicator in patients with head and neck cancer ${ }^{7}$.

The relationship between the values of salivary mucins and $\mathrm{pH}$ and the correlation of the laryngeal cancer etiology has been assessed from the premise that xerostomia is a risk factor by altering the saliva quality and the autoimmune disease has a decrease in the value of $\mathrm{pH}$ and salivary flow. As a direct consequence decreases the value of spinnbarkeit which measures the ability of the mucous layer to adhere to the epithelium can cause alteration of the mucin layer in the oral cavity. Increasing salivary mucin concentration associated with diabetes leads to the impossibility of creating the mucosal protective layer and by this algorithm diabetes becomes a risk factor for squamous cell head and neck cancers ${ }^{8}$.

Xerostomia and impaired quality of life by reducing salivary volume and altered saliva quality are identified in many studies. Diabetes mellitus and low metabolic control are associated with adverse effects on oral health. Radiotherapy is also causing xerostomia and altered $\mathrm{pH}$ and bacterial flora of the oral cavity with di- rect consequences in worsening of radiomucositis and the appearance of dental caries ${ }^{9,10}$.

Hyperglycemia of the patients benefiting from nutritional support in hospitalization is common, reaching up to $30 \%$ in patients receiving enteral nutritional support and in more than half of patients in patients receiving parenteral nutrition ${ }^{11}$.

Corticosteroids are often administered to cancer patients in combination with chemotherapy for antiemetic purposes to prevent vomiting induced by chemotherapy or allergic effects. In patients diagnosed with and treated with radiotherapy or radiochemistry for neck cancers, dexamethasone is often used as an anti-edematous drug with a long half-life and an anti-inflammatory effect more than other corticosteroids. Generally administered over long periods of time for patients receiving 2-4 cycles of induction chemotherapy followed by concomitant radiotherapy or radio-chemotherapy for 7 weeks, adverse effects are not rare, the most common being hyperlipidemia, adrenal suppression, growth suppression, amenorrhea, gynecomastia ${ }^{12}$.

Hyperglycemia and insulin resistance are commonly associated with the use of corticosteroids downregulation of glucose transporter 4 in muscle, associated with increased insulin required for the uptake of glucose into cells, and with increased hepatic glucose production, blocking inhibition of insulin binding to the cell insulin receptor. Corticosteroids also inhibit the production of insulin by the cells ${ }^{13}$.

The use of glucocorticoids may exacerbate pre-diabetes or undiagnosed diabetes and may trigger a hyperglycemic non-ketotic hyperosmolar coma for patents who already have a previously manifested clinical diabetes. Being aware that symptoms of hyperglycemia such as thirst, dry mouth, polyuria, and lethargy are common in tumor pathologies and often associated with oncological treatments, the diagnosis of diabetes present at the onset of oncological treatment is often late ${ }^{14}$.

Family history of diabetes and the patient history of gestational diabetes, older age, obesity, and the steroids doses required are considered predictive factors for glucocorticoid induced diabetes by Clement and collaborators ${ }^{15}$.

Patients with pre-existing diabetes require close monitoring of oral anti-diabetic therapy on corticosteroid therapy but are often inadequate. Patients treated with insulin prior to glucocorticoid administration will often require basal and postprandial doses for appropriate glycemic control ${ }^{16}$. 
The addition of chemotherapy to radiotherapy in the treatment of locally advanced squamous cell carcinoma has shown significant benefit in overall survival with the most eloquent evidence for concurrent administration of chemotherapy and radiotherapy. Al Saraf et al. concluded 30 years ago that the combination of Cisplatin and radiotherapy is an effective and safe treatment in patients with advanced head and neck cancer and today platinum based chemotherapy is part of all the multidisciplinary therapeutic recommendations for locally advanced head and neck cancers. Concurrent chemo-radiotherapy using weekly Cisplatin at $40 \mathrm{mg} / \mathrm{m}^{2}$ per week and the standard dose of $100 \mathrm{mg}$ $/ \mathrm{m}^{2}$ Cisplatin three-weekly are used concurrently with radiotherapy ${ }^{17,18}$.

The use of chemotherapy induction followed by radio-chemotherapy or radiotherapy as the unique treatment method remains a controversial topic. However, the platinum induction regimens and 5-fluorouracil $(\mathrm{PF})$-containing induction regimens demonstrated a significant survival benefit compared to individual loco-regional treatment. The triplet combination of Docetaxel, Cisplatin, and 5-fluorouracil used as an induction regimen has been shown to be more effective than platinum-based platinum-based chemotherapy or platinum \&5-fluorouracil.

The development of a hyperglycemic crisis in head and neck cancer patients benefiting from platinum-based chemotherapy has also been reported. Huang et al reports from a total of 185 patients, 3.8\% who developed type 2 diabetes after initial chemotherapy. 3 patients developed diabetic ketoacidosis and the hyperglycemic crisis in this study group, complications occurring in patients with multiple comorbidities ${ }^{20}$. Intrinsic factors have been associated with acute skin toxicity in breast cancer radiotherapy ${ }^{21}$. Diabetes is identified as a risk factor in studies that include pelvic irradiation, es- pecially for prostate cancer patients and just like smoking and hypertension, and atherosclerosis is associated with bowel tardive toxicity ${ }^{23}$.

The CT / IRM evaluation of the induction chemotherapy response is poorly correlated with the pathological response especially in the tumors of the oral cavity and the larynx. In these cases, RECIST criteria may not be sensitive suggestive for predicting response after induction chemotherapy ${ }^{24}$.

\section{CONCLUSIONS}

The study does not show that the presence of diabetes increases the rate of toxicity in head and neck cancers except radiomucositis. However, the association of high blood pressure and type 2 uncontrolled diabetes at the onset of radiotherapy limits the administration of glucocorticoids and affects the quality of life of patients. It is necessary to monitor the late toxicity that can be potentiated by microangiopathic diabetic complications and the evaluation of a larger group of patients.An extensive study including the correlation of dosimetric parameters with acute and late toxicities in head and neck cancers with the doses received by different organs is necessary to assess whether there is a need to limit the dose of radiation to the oral cavity and parotid glands below the current recommended limits to prevent xerostomia and oral mucositis.

\section{Compliance with ethics requirements:}

The authors declare no conflict of interest regarding this article.

The authors declare that all the procedures and experiments of this study respect the ethical standards in the Helsinki Declaration of 1975, as revised in 2008(5), as well as the national law. Informed consent was obtained from all the patients included in the study.

\section{References}

1. Foreman A., Lee DJ., McMullen C., de Almeida J., Muhanna N., Gama RR, Giuliani M., Liu G., Bratman SV, Huang SH, O'Sullivan B, Song Y, Xu W, Goldstein DP. Impact of Type 2 Diabetes Mellitus on Survival in Head and Neck Squamous Cell Carcinoma. Otolaryngol Head Neck Surg. 2017 Oct;157(4):657-663.

2. Coller HA. Is cancer a metabolic disease? Am J Pathol. 2014 Jan;184(1):4-17

3. Cook CB, Kongable GL, Potter DJ, et al. Inpatient glucose control: a glycemic survey of 126 U.S. hospitals. J Hospital Med. 2009;4:E7-E14.

4. Feng Z, Liu L, Zhang $C$, Zheng T, Wang J, Lin M, Zhao Y, Wang $X$, Levine AJ, Hu W Chronic restraint stress attenuates p53 function and promotes tumorigenesis. ProcNatlAcadSci U S A. 2012 May 1; 109(18):7013-8.

5. Foreman A., Lee DJ., McMullen C., de Almeida J., Muhanna N., Gama RR., Giuliani M., Liu G., Bratman SV., Huang SH., O'Sullivan B., Song Y., Xu W., Goldstein DP.. Impact of Type 2 Diabetes Mellitus on Survival in Head and Neck Squamous Cell Carcinoma.Otolaryngol Head Neck Surg. 2017 Oct;157(4):657663 
6. Singh B., Bhaya M, Zimbler M, Stern J, Roland JT, Rosenfeld RM, Har-El G, Lucente FE. Impact of comorbidity on outcome of young patients with head and neck squamous cell carcinoma. Head Neck. 1998 Jan;20(1):1-7.

7. Singh B1, Bhaya M, Stern J, Roland JT, Zimbler M, Rosenfeld RM, Har-El G, Lucente FE. Validation of the Charlson comorbidity index in patients with head and neck cancer: a multi-institutional study. Laryngoscope. 1997 Nov;107(11 Pt 1):1469-75.

8. Menicagli R, Bolla G, Menicagli L, Esseridou A. The Possible Role of Diabetes in the Etiology of Laryngeal Cancer.Gulf J Oncolog. 2017 Jan;1(23):44-51.

9. Molania T, Alimohammadi M, Akha O, Mousavi J, Razvini R, Salehi M. The effect of xerostomia and hyposalivation on the quality of life of patients with type II diabetes mellitus. Electron Physician. 2017 Nov 25;9(11):5814-5819. doi: 10.19082/5814. eCollection 2017 Nov.

10. Arrifin A, Heidari E, Burke M, Fenlon MR, Banerjee A. The Effect of Radiotherapy for Treatment of Head and Neck Cancer on Oral Flora and Saliva.Oral Health Prev Dent. 2018;16(5):425-429. doi: 10.3290/j.ohpd.a41364

11. Aidar R., Guillermo E. Umpierrez. Management of Hyperglycemia During Enteral and Parenteral Nutrition Therapy CurrDiab Rep. 2013 Feb; 13(1): 155-162

12. Vigneri P, Frasca F, Sciacca L, Pandini G, Vigneri R. Diabetes and cancer. EndocrRelat Cancer. 2009;16:1103-23.

13. Poulson J. The management of diabetes in patients with advanced cancer. J Pain Symptom Manage. 1997;13:339-46.

14. Fardet L, Kassar A, Cabane J, Flahault A. Corticosteroid-induced adverse events in adults: frequency, screening and prevention. Drug Saf. 2007;30:861-81.

15. Clement S, Braithwaite SS, Magee M,et al. : Management of diabetes and hyperglycemia in hospitals. Diabetes Care 27:553591,2004
16. Volgi J, Baldwin D: Glucocorticoid therapy and diabetes management. NursClin North Am 36:333-339, 2001

17. Al-Sarraf M, Pajak TF, Marcial VA, Mowry P, Cooper JS, Stetz J, Ensley JF, Velez-Garcia E. Concurrent radiotherapy and chemotherapy with cisplatin in inoperable squamous cell carcinoma of the head and neck. An RTOG Study. Cancer. 1987 Jan 15;59(2):259-65.

18. Iqbal MS, Chaw C, Kovarik J, Aslam S, Jackson A, Kelly J, Dobrowsky W, Kelly C. Primary Concurrent Chemoradiation in Head and Neck Cancers with Weekly Cisplatin Chemotherapy: Analysis of Compliance, Toxicity and Survival. Int Arch Otorhinolaryngol. 2017 Apr;21(2):171-177.

19. Vokes E.E. Induction chemotherapy for head and neck cancer: recent data. Oncologist. 2010;15 Suppl 3:3-7. doi: 10.1634/ theoncologist.2010-S3-03.

20. Huang CY, Lin YS, Liu YH, Lin SC, Kang BH. Hyperglycemia crisis in head and neck cancer patients with platinum-based chemotherapy. J Chin Med Assoc. 2018 Dec;81(12):1060-1064.

21. Mitchell Machtay, Jennifer Moughan, Andrew Trotti, Adam S. Garden, Randal S. Weber, Jay S. Cooper, Arlene Forastiere, and K. Kian Ang. Factors Associated With Severe Late Toxicity After Concurrent Chemoradiation for Locally Advanced Head and Neck Cancer: An RTOG Analysis. J ClinOncol. 2008 Jul 20; 26(21): 3582-3589

22. Grodsky MB., Sidani SM. Radiation proctopathy. Clin Colon Rectal Surg. 2015;28(2):103-111.

23. Zaorsky NG., Shaikh T., Ruth K. Prostate Cancer Patients With Unmanaged Diabetes or Receiving Insulin Experience Inferior Outcomes and Toxicities After Treatment With Radiation Therapy. ClinGenitourin Cancer. 2017 Apr;15(2):326-335.e3.

24. Patil $V$, Noronha $V$, Joshi $A$, et al. Is there a limitation of RECIST criteria in prediction of pathological response, in head and neck cancers, to postinduction chemotherapy? ISRN Oncol. 2013;2013:259154. 
